\title{
Phenolic Analysis and Characterization of Palm Sugar (Arenga pinnata) Produced by The Spray dryer
}

\author{
JAYANUDIN ${ }^{\star}$, TEGUH KURNIAWAN* and INDAR KUSTININGSIH \\ Chemical Engineering Department, Universitas Sultan Ageng Tirtayasa, \\ Jl. Jendral Sudirman km. 3 Cilegon, Indonesia. \\ ${ }^{*}$ Corresponding author E-mail: jayanudin@untirta.ac.id \\ http://dx.doi.org/10.13005/ojc/350116
}

(Received: December 13, 2018; Accepted: January 05, 2019)

\begin{abstract}
The effect of spray dryer inlet temperature on characterization and total phenolic content of palm sugar has been studied. The spray dryer operating conditions used were $160^{\circ} 220^{\circ} \mathrm{C}$ inlet temperature with a feed flow rate of $2 \mathrm{~L} / \mathrm{h}$, while for outlet temperature was $85^{\circ} \mathrm{C}$. The high inlet temperature produced a higher crystallinity of sucrose and did not agglomerate and not sticky. However, the high temperature of the spray dryer inlet produced palm sugar that was browner than the low temperature one. The effect of increasing temperature of spray dryer produced irregular total phenolic. The total phenolic at $220^{\circ} \mathrm{C}$ was higher than $200^{\circ} \mathrm{C}$. Likewise, the temperature of $180^{\circ} \mathrm{C}$ generated total phenolic was higher than the temperature of $160^{\circ} \mathrm{C}$. The total phenolic of palm sugar analyzed in this study was quite large within the range of $49 \pm 0.01$ to $63.6 \pm 0.01 \mathrm{mg}$ of $\mathrm{GAE} / 100 \mathrm{~g}$ samples.
\end{abstract}

Keywords: Palm sap, Palm sugar, Spray dryer, Total phenolic.

\section{INTRODUCTION}

Arenga pinnata contains the sap that has a sweet and pleasant taste. The sweet taste of palm sap because of the high sugar content ( $93 \mathrm{~g} / 100 \mathrm{~g}$ of dry matter) such as sucrose, glucose, fructose, and maltose. In addition, the palm sap contains protein ( $5 \mathrm{~g} / 100 \mathrm{~g}$ dry matter basis) and mineral elements ${ }^{1}$. Palm sap is also beneficial for health, palm juice contains phenolic compounds of $246 \mathrm{mg}$ of gallic acid/100 gram. Phenolic compounds in juice are useful for preventing several chronic diseases, such as cancer, Parkinson's disease, heart disease, etc ${ }^{1}$. The weakness of palm juice is easily damaged and deteriorated due to Saccharomyces cerevisiae contamination. Lime and jackfruit tree bark is traditionally added to preserve the palm sap from deterioration. Arenga palm sap is widely used as a material for palm sugar production using traditional methods. The palm sap is crystallized in a pan with direct heating. The phenolic compounds in palm sugar can be destroyed due to open heating with high temperatures ${ }^{2}$. Sugar processing requires proper technology to minimize the loss of bioactive components from the palm sap.

This is an Open Access article licensed under a Creative Commons license: Attribution 4.0 International (CC- BY). Published by Oriental Scientific Publishing Company @ 2018 
Traditional palm sugar processing by using open pan evaporator produced sugar with brown color because of high temperature and long heat treatment which favored browning and Maillard reactions ${ }^{3,4}$. Another disadvantage is that it leads to higher sucrose inversion and hydroxy methyl furfural formation with less glucose and fructose. A vacuum evaporator that uses lower temperatures could reduce the sucrose inversion. Every technology used to produce palm sugar has advantages and disadvantages. The choice of technology to produce palm sugar depends on its purposes. Palm sugar produced with open pan evaporator and vacuum evaporator may not be suitable for pharmaceutical requirements because of low phenolic content. One technology that can be used is spray dryer. Palm sugar produced using spray drying technology is able to produce a higher total phenolic than a vacuum evaporator. This total phenolic value correlates positively with antioxidant activity. The higher total phenolic content leads to the greater the antioxidant activity.

Spray dryer technology has the advantage of being able to maintain the antioxidant content starting from palm sap to the crystallized palm sugar form. Temperature changes in producing palm sugar can affect the phenolic content of palm sugar. The study reported by Aeimsard et al., ${ }^{5}$ increased the evaporator temperature from $40^{\circ} \mathrm{C}$ to $60^{\circ} \mathrm{C}$ causing the phenolic content decrease from $16.29 \pm 0.53$ to $4.04 \pm 0.58$ (mg of gallic acid/100 g). The phenolic content of palm sugar using spray drying method was $57.43 \pm 3.4$ to $63.72 \pm 4.7$ (mg of FAE $/ 100 \mathrm{~g}$ of sap) using a temperature of $136.36^{\circ} \mathrm{C}-203.64^{\circ} \mathrm{C}^{1}$. Although using a higher temperature the phenolic content of palm sugar with a spray dryer is still higher. This is because of the contact between the palm sap droplet with hot air occurs very quickly which minimize the loss of phenolic content in sugar. The temperature of the spray dryer could affect phenolic contents in palm sugar. In addition, the temperature of the spray dryer also affects the characteristics of palm sugar, such as the color of sugar, crystallization of sucrose, and the morphology of palm sugar. This study aims to determine the characterization of palm sugar and phenolic content on the temperature effect of spray dryers.

\section{MATERIALS AND METHODS}

\section{Materials}

Palm sap was obtained from local palm sugar farmer in Mancak, Banten Province-Indonesia, methanol was provided from Merck, Folin-Ciocalteu reagent was obtained from Merck (Darmstadt, Germany) used to the analysis of the total phenolic content of palm sugar and used to a standard calibration curve was prepared using different concentrations of gallic acid in methanol. The spray dryer set up was manufactured in Chemical Engineering Unit Operations Laboratory, Universitas Sultan Ageng Tirtayasa as seen in Figure 1.

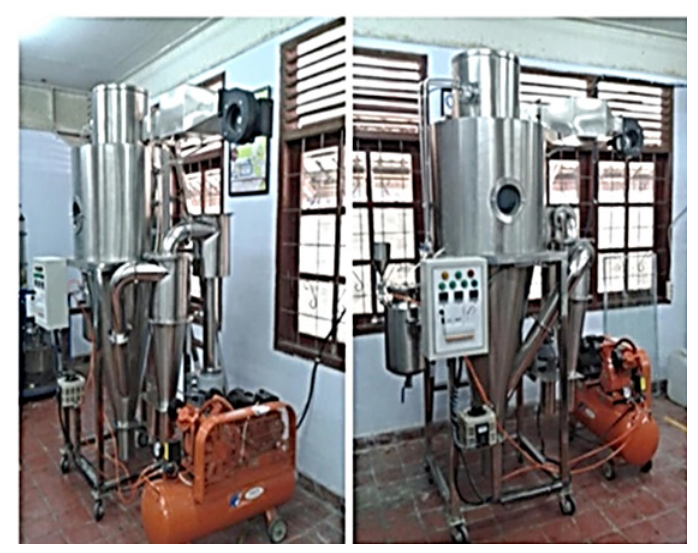

Fig. 1. Spray dryer for palm sap crystallization

\section{Production of palm sugar using spray dryer technology}

Palm sap obtained from a farmer was then filtered to remove insects and other impurities. Palm sugar was put into the spray dryer feed tank. The initial stage was flowing air and contact with a heater which was set at $140^{\circ} \mathrm{C}$ for the inlet temperature of a spray dryer and the outlet temperature was $85^{\circ} \mathrm{C}$. Palm sap was flowed at $2 \mathrm{~L} / \mathrm{h}$ from the feed tank to the nozzle to be atomized and contacted with hot air. The powder of palm sugar formed was stored in the product tank. The same step was used to produce sugar with the inlet temperature were $160^{\circ} \mathrm{C}$, $180^{\circ} \mathrm{C}, 200^{\circ} \mathrm{C}$, and $220^{\circ} \mathrm{C}$. The palm sugar formed was analysed for changes in phenolic content and characterized using SEM, FTIR, and XRD.

\section{Characterization of palm sugar X-ray diffraction (XRD) Analysis}

Sugar crystallinity samples were studied by using powder $\mathrm{X}$-ray diffraction (XRD, Shimadzu 7000 Maxima-X). Radiation of $\mathrm{Cu}$-Kalpha was used 
for the sample analysis. The scanning rate was $2 \%$ min from $2 \theta$ of $2^{\circ}$ to $90^{\circ}$ with a step size $0.02^{\circ}$.

\section{Fourier Transform Infrared Spectroscopy (FTIR) Analysis}

Functional group analysis of palm sugar was analysed by Fourier transform infrared spectroscopy (FTIR) from spectrophotometer Shimadzu IR, KBr Pellet: Absorbance of IR by Solid samples are measured in $\mathrm{KBr}$ pellets, which is prepared by pressing mixture of $1: 100$ solid sample: $\mathrm{KBr}$, wavenumber operated with a range between 400 and $4000 \mathrm{~cm}^{-1}$.

\section{Scanning Electron Microscope (SEM)}

Morphological analysis of palm sugar was used a scanning electron microscope (SEM) with JEOL JSM-6510 LV type. Palm sugar powder coated with platinum, acceleration voltage: 0.5 to $30 \mathrm{kV}$, with a high resolution of high vacuum mode: $3.0 \mathrm{~nm}$ at $30 \mathrm{kV}$ and low vacuum mode: $4.0 \mathrm{~nm}(30 \mathrm{kV})$.

\section{Analysis of total phenolic palm sugar}

Analysis of total phenolic palm sugar referred to the study reported by Maurya and Singh ${ }^{6}$ and Abdelhady et al., ${ }^{7}$. The Folin-Ciocalteu reagent was used to analysis total phenolic of palm sugar. Gallic acid used as a standard and total phenolic was expressed as $\mathrm{mg}$ gallic acid equivalent/g sample (mg GAE/g sample). Palm sugar was prepared in methanol and each sample was put into a test tube and mixed with $2.5 \mathrm{~mL}$ of a 10-fold dilute Folin-Ciocalteu reagent and $2 \mathrm{~mL}$ of $7.5 \%$ sodium carbonate. The test tube was closed and let stand for $30 \mathrm{~min}$ at room temperature. The samples were analysed using a UV-Vis spectrophotometer with a wavelength of $760 \mathrm{~nm}$. The Folin-Ciocalteu reagent was sensitive to polyphenol content resulting in a blue color during a reaction. The blue colour was measured spectrophotometrically and total phenolic content can be determined.

\section{RESULTS AND DISCUSSION}

Effect of spray dryer temperature on the colour of palm sugar

The discoloration of palm sugar caused by the temperature difference of the spray dryer can be seen Figure 2.

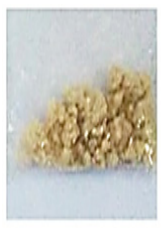

$T=160^{\circ} \mathrm{C}$

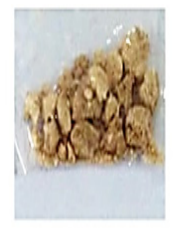

$\mathrm{T}=180^{\circ} \mathrm{C}$

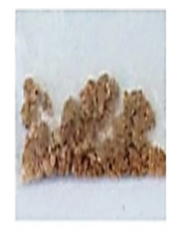

$\mathrm{T}=200^{\circ} \mathrm{C}$

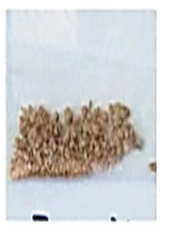

$T=220^{\circ} \mathrm{C}$
Fig. 2. The Effect of spray dryer temperature on palm sugar colour

Figure 2 showed that the temperature of the spray dryer $220^{\circ} \mathrm{C}$ produces palm sugar which was darker than at temperatures of $160^{\circ} \mathrm{C}, 180^{\circ} \mathrm{C}$, and $200^{\circ} \mathrm{C}$. It could be concluded that increased the spray dryer temperature made the colour of palm sugar browner. Maillard reaction is reaction between reducing sugars and especially free amino acids and peptides (usually proteins) when heated. Maillard reaction is complex reactions that depend on factors such as $\mathrm{pH}$ and temperature. Illustration of Maillard reaction can be seen in Figure 3.

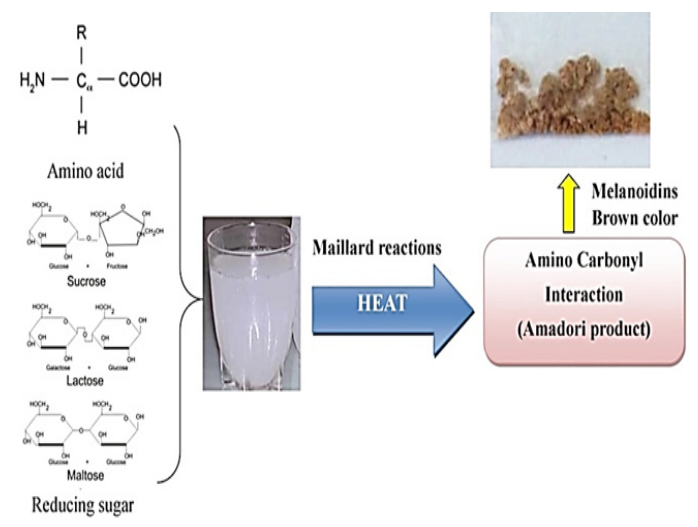

Fig. 3. Illustration of the Maillard reaction which causes browning of palm sugar. High temperatures and long heat treatment cause higher inversions of sucrose formation and furfural hydroxymethyl with little glucose and fructose

Maillard browning caused a decrease in the quality of the original protein structure (primary, secondary and tertiary) and hence reduces functionality (such as solubility). Browning with Maillard reactions occurs faster in alkaline than in acid conditions and also at intermediate water activity. Maillard browning produces browning of the sugar, and loss of essential amino acids, lysine, digestibility, and solubility 8,9 .

Palm sugars produced from the spray dryer temperature were $160^{\circ} \mathrm{C}, 180^{\circ} \mathrm{C}$, and $200^{\circ} \mathrm{C}$ stick together and form large lumps. While 
at a temperature of $220^{\circ} \mathrm{C}$ it produced palm sugar powder that did not stick together as shown in Fig. 2. Cohesion-adhesion properties that cause the palm sugar powder to become sticky. Cohesion is an internal property that leads to the formation of large lumps caused by the attraction between particles (particle-particle stickiness). Adhesion is an interfacial property and the tendency of particles to stick with the spray dryer wall. Adhesion-cohesion force factors are a consideration in designing spray dryers to overcome the stickiness problem. Other factors that cause stickiness in the production of sugar using spray dryers are high hygroscopicity, thermoplasticity and low glass transition temperature (Tg) from low molecular weight substances ${ }^{10}$.

Another factor that caused palm sugar to stick was amorphous glass state. In the drying process, the viscosity and surface tension become very high around the level of critical water activity which depended on composition and temperature. The state of high viscosity/high surface tension was referred to as a rubbery state. Further drying leads to the presence of solid glass that is not sticky. There is a region between rubbery and non-sticky states called the glass transition region. The problem of stickiness in spray drying between the powder and equipment surface was related to the glass transition state, or sometimes called the plastic state ${ }^{11}$. The high-temperature of spray dryer was needed to produce powdered palm sugar that non-sticks together but could cause browning and reduce its phenolic content.

\section{Characterization of palm sugar from a spray dryer FTIR analysis}

FTIR analysis was performed to determine the chemical structure of palm sugar from a spray dryer. Palm sugar analysed was from a spray dryer that used temperatures of $180^{\circ} \mathrm{C}$ and $220^{\circ} \mathrm{C}$. This difference was used to determine the chemical structure changes as a result of increased temperature. Fig. 4 presented analysis of FTIR for palm sugar from spray dryer and compared with commercial palm sugar which was traditionally processed.

Analysis of Fourier Transform Infra-Red (FTIR) Spectrophotometer was used to determine the difference in peak absorbance of functional groups from palm sugar resulting from the difference of spray dryer inlet temperature and compared with commercial jaggery as shown in Fig. 4. Peak absorbance of palm sugar functional groups from $220^{\circ} \mathrm{C}$ spray dryer temperature was the same as commercial jaggery. The peak absorbance of palm sugar was produced from a spray dryer at $180^{\circ} \mathrm{C}$ which has a shift in the peak absorbance of the functional group. The peak absorbance of functional groups produced from palm sugar at a temperature of $180^{\circ} \mathrm{C}, 220^{\circ} \mathrm{C}$, and commercial jaggery can be shown in Table 1.

The main functional groups of sucrose were $\mathrm{OH}, \mathrm{C}-\mathrm{H} \mathrm{sp}{ }^{3}$ and $\mathrm{C}-\mathrm{O}$. This functional group is also found in palm sugar as shown in Table 1.

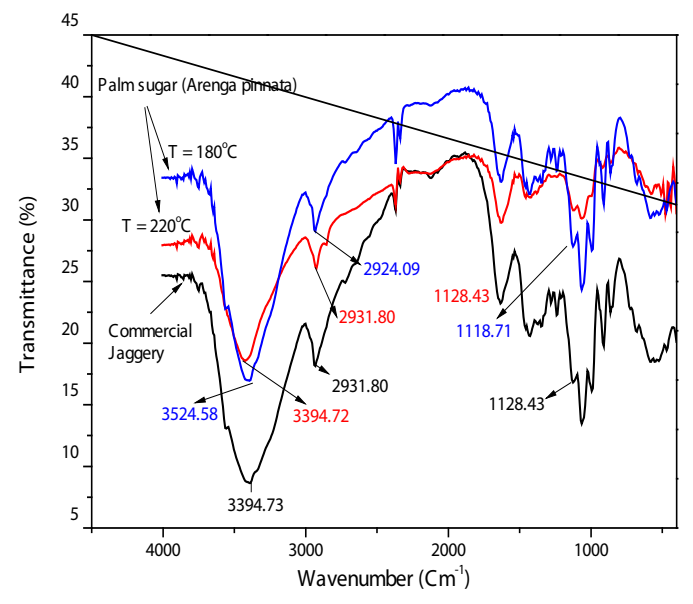

Fig. 4. FTIR analysis of palm sugar (Arenga pinnata) compared to commercial jaggery. Palm sugar was prepared with a spray dryer at $180^{\circ} \mathrm{C}$ and $220^{\circ} \mathrm{C}$

Table 1: FTIR analysis for palm sugar prepared from spray dryers at inlet temperatures of 180 and $200^{\circ} \mathrm{C}$, and also compared with commercial jaggery

\begin{tabular}{cccc}
\hline Fuctional groups & \multicolumn{3}{c}{ Wavenumber $\left(\mathrm{cm}^{-1}\right)$} \\
& \multicolumn{2}{c}{ Palm sugar } & Commercial jiggery \\
& $\mathrm{T}=180^{\circ} \mathrm{C}$ & $\mathrm{T}=220^{\circ} \mathrm{C}$ & \\
\hline O-H & 3524.58 & 3394.72 & 3394.73 \\
$\mathrm{C}-\mathrm{H} \mathrm{sp}$ (alkane) & 2924.09 & 2931.08 & 2931.08 \\
$\mathrm{C}-\mathrm{O}$ & 1118.71 & 1128.41 & 1128.41 \\
\hline
\end{tabular}

\section{X-ray diffraction analysis}

The XRD patterns in Fig. 5 show that the sugar produced by spray dryer was mainly sucrose (Card No. 24-1977). The XRD patterns were similar with XRD pattern of the pure sucrose reported in literature ${ }^{12,13}$. 


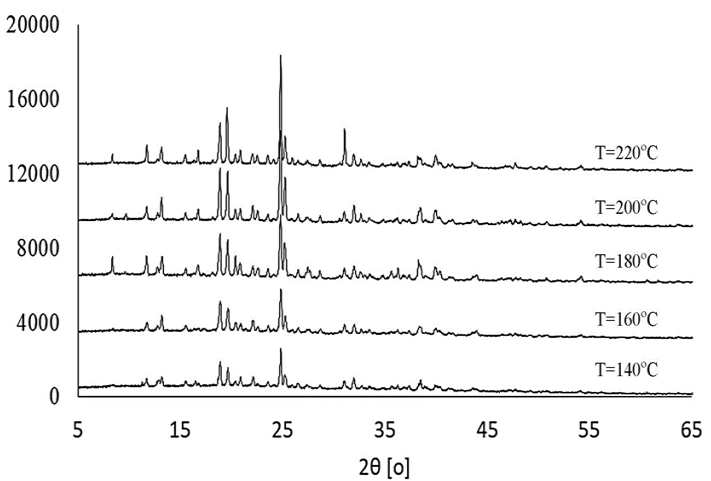

Fig. 5. The crystallinity of palm sugar based on the difference in spray dryer inlet temperature. Offset by 3000

The sucrose XRD pattern implied that the spray dryer produced was crystalline sucrose not the amorphous one. Relatively high temperature operations $\left(140-220^{\circ} \mathrm{C}\right)$ lead to crystalline sucrose. Morrow et al., ${ }^{14}$ investigated that amorphous sucrose was formed by using spray dryer at very low temperature $65^{\circ} \mathrm{C}$. The main peaks of crystalline sucrose were indicated by $2 \theta=8.4^{\circ}, 11.8^{\circ}, 13.2^{\circ}$, $18.8^{\circ}, 19.7^{\circ}, 31.1^{\circ}, 32.1^{\circ}$. The impurities peaks were also detected in the XRD patterns of the spry dried sugar i.e., at $2 \theta=9.9^{\circ}$ which was observed at temperature $180^{\circ} \mathrm{C}$ and $200^{\circ} \mathrm{C}$. It most likely the reducing sugars such as glucose and fructose were presence in the spray dried sugar as the impurities. The form of reducing sugar due to the acidity of palm sugar is high because of the fermentation process during tapping sap and waiting for the spray dryer processing ${ }^{15}$. It can be seen clearly from Fig. 5 that the spry dryer temperature significantly affected the crystallinity of sucrose. Lower temperature favored low crystallinity of sucrose as suggested by the XRD pattern of spray dried sucrose at $\mathrm{T}=140^{\circ} \mathrm{C}$ which showed the lowest intensity peaks. The sucrose crystallinity was gradually increased as the temperature getting higher. It is most likely moisture content of sugar produced by low temperature was still high lead to the low crystalline sucrose. The sugar relative crystallinity was determined by calculating area under the main peaks $2 \theta$ within the range of $8-30^{\circ}$.

$\mathrm{x}=$ temperature spray dryer

Table 2 presented the relative crystallinity of spray dried sucrose with respect to the highest intensity of XRD peaks at temperature $220^{\circ} \mathrm{C}$. The crystallinity of temperature $140^{\circ} \mathrm{C}$ and $160^{\circ} \mathrm{C}$ was not much different. The sucrose crystallinity noticed increase significantly at temperature $180^{\circ} \mathrm{C}$. This finding is in agreement with Imtiaz-UI-Islam and Langrish16 who introduced the concept of stickiness barrier by using commercial sucrose pure grade. They found that the Spray dryer yielded less crystallized sucrose at temperature between $105-165^{\circ} \mathrm{C}$ because of stickiness barrier which is related to the difference between the operation temperatures and the glass-transition temperatures of sucrose. It is worthen to know that the glass temperature of sucrose was $60^{\circ} \mathrm{C}$ and could be predicted by molecular dynamic simulation ${ }^{17}$. The higher operating temperature was supported the high yield and crystallinity.

Table 2: Relative crystallinity of spray dried samples

\begin{tabular}{ccc}
\hline No & Temperature $\left({ }^{\circ} \mathrm{C}\right)$ & Relative crystallinity \\
\hline 1 & 140 & $92 \%$ \\
2 & 160 & $93 \%$ \\
3 & 180 & $97 \%$ \\
4 & 200 & $98 \%$ \\
5 & 220 & $100 \%$ \\
\hline
\end{tabular}

\section{Scanning electron microscope (SEM) analysis}

The SEM image of samples on various spray dryer temperature could be seen in Fig. 6. It showed the palm sugar generally had rectangular shaped especially in Fig. 6A. This result was different from previous researchers. Morrow et al., ${ }^{14}$ reported that spray dryer method obtained palm sugar with spherical particles with a generally smooth surface and the particles sticking together.

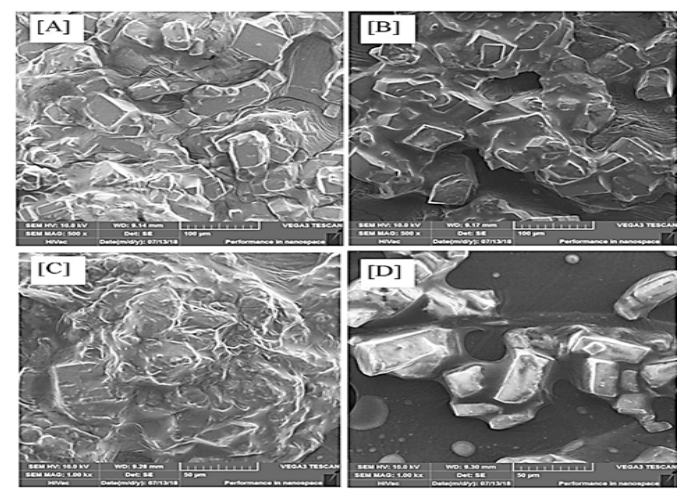

Fig. 6. SEM Images of palm sugar on various temperature of spray drier: $[A] 160^{\circ} \mathrm{C},[\mathrm{B}] 180^{\circ} \mathrm{C},[\mathrm{C}] 200^{\circ} \mathrm{C}$, and [D] commercial jaggery 
This rectangular shaped was almost same with morphology of commercial jaggery at Fig. 6 . However, Fig. 6C shows a sticky and agglomerated product instead of powder. The agglomeration is most likely occurred due to caramelization. Khuenpet et al., ${ }^{18}$ reported the caramelization occurred when the sucrose with high remaining moisture was exposed to heat. It indicated that the spray dryer temperature plays an important role on the change in shape and morphology of palm sugar.

\section{Effect of spray dryer temperature on the total phenolic content of palm sugar}

Phenolic content is the main antioxidant that could be found in plants and fruits. This phenolic content is very beneficial for health and safe from adverse side effects. Phenolic content has a variety of biological activities to protect against various diseases such as cancer, diabetes, inflammation, arthritis, and cardiovascular disease. However, phenolic content is easily eroded during the process, especially those that use heating, so it can reduce its quality ${ }^{19}$. Table 3 showed the effect of the temperature of the spray dryer on the total phenolic content of palm sugar.

Table 3 showed an increase in inlet temperature of the spray dryer produced irregular total phenolic. The total phenolic from the spray dryer inlet temperature of $180^{\circ} \mathrm{C}$ was higher than $220^{\circ} \mathrm{C}$. This result was different from that reported by Lasekan ${ }^{1}$, the total phenolic content was generally reduced by $10 \%$ at a high inlet temperature of $203.64^{\circ} \mathrm{C}$. The spray dryer inlet temperature used was $136.3^{\circ} \mathrm{C}$ to $203.64^{\circ} \mathrm{C}$ and produced total phenolic of $57.43 \pm 3.4$ to $63.72 \pm 4.7 \mathrm{mg}$ of GAE/100 $\mathrm{g}$ sample. The irregular total phenolic value was probably caused by the sample of palm sap used for different days of sap tapping from the palm tree. The time of taking different palm sap could vary the total phenolic content in palm sugar.

Table 3: The effect of temperature on total phenolic in palm sugar

\begin{tabular}{cc}
\hline Temperature $\left({ }^{\circ} \mathrm{C}\right)$ & $\begin{array}{c}\text { Total Phenolic in palm sugar } \\
\text { (g GAE/g sample) }\end{array}$ \\
\hline 160 & $53.7 \pm 0.01$ \\
180 & $63.6 \pm 0.01$ \\
200 & $48 \pm 0.01$ \\
220 & $52.6 \pm 0.01$ \\
\hline
\end{tabular}

Mean \pm SD, $n=2$
Nevertheless, the total phenolic value produced in this study was almost the same as the research conducted by Lasekan ${ }^{1}$ even though this research was used a higher temperature spray dryer. The total phenolic of palm sugar produced in this study was still higher than the palm sugar using a vacuum drying method. Although, the temperature used was lower at $40-60^{\circ} \mathrm{C}$ and the total phenolic that resulted from $2.14 \pm 0.19$ to $16.29 \pm 0.53 \mathrm{mg}$ of $\mathrm{GAE} / 100 \mathrm{~g}$ of sample 5 . This showed that the spray drying method was more effective than the direct heating method or the vacuum drying method.

\section{CONCLUSION}

Spray drying was an effective method to avoid the browning effect on palm sugar and was able to minimize the loss of phenolic content in palm sugar. Increased temperature of spray dryer caused a browning effect on palm sugar as evidenced by the spray dryer inlet temperatures of $200^{\circ} \mathrm{C}$ and $220^{\circ} \mathrm{C}$ which produce palm sugar which was darker than the temperatures of $160^{\circ} \mathrm{C}$ and $180^{\circ} \mathrm{C}$ but at this temperature, palm sugar became an agglomeration and sticky. While at $220^{\circ} \mathrm{C}$ produced palm sugar in the form of powder and not sticky. The total phenolic produced was irregular because of increasing the spray dryer temperature. Total phenolic values obtained from $48^{\circ} 0.1$ to $63.6^{\circ} 0.01 \mathrm{mg}$ of GAE $/ 100 \mathrm{~g}$ sample. The total phenolic of palm sugar from the spray dryer was higher than the vacuum drying method even though the temperature was lower. This showed that the spray dryer method was more effective with regard to the total phenolic content than vacuum dryers.

\section{ACKNOWLEDGEMENT}

The authors would like to acknowledge The Islamic Development Bank (IDB) - Universitas Sultan Ageng Tirtayasa (UNTIRTA) for providing grant project no.593/UN43.9/PL/2018.

\section{CONFLICT OF INTEREST STATEMENT}

All authors in this article declare that there are no conflicts of interest. 


\section{REFERENCES}

1. Lasekan, O. Dry. Technol., 2014, 32, 398-407.

2. Tomomatsu, A.; Itoh, T.; Wijaya, C.H.; Nasution, Z.; Kumendong, J.; AkIra, M. Japanese J. Trop. Agric., 1996, 40, 175-181

3. Ho, C.W.; Aida, W.M.W.; Maskat, M.Y.; Osman, H. Food Chem., 2007, 102, 1156-1162

4. Apriyantono, A.; Aristyani, A.; Nurhayati; Lidya, Y.; Budiyanto, S; Soekarto, S.T. Int. Congr. Ser., 2002, 1245, 275-278

5. Aeimsard, R.; Benjawan, T.; Rattakorn, J; Lekhavat, S. J. Food Sci. Agric. Technol., 2015, 1, 126-130.

6. Maurya, S.; Singh, D. Int. J. PharmTech Res., 2010, 2, 2403-2406.

7. Abdelhady, M.I.S.; Motaal, A.A.; Beerhues, L. Am. J. Plant Sci., 2011, 847-850.

8. Manley, D. Sugars and syrups as biscuit ingredients. In: Manley's Technology of Biscuits, Crackers and Cookies: Fourth Edition. Woodhead Publishing Limited., 2011.

9. Intipunya, P.; Bhandari, B.R. Chemical deterioration and physical instability of food and beverages. Chapter 22. In: Skibsted L, Risbo $J$, Andersen M(eds). Chemical deterioration and physical instability of food and beverages. Woodhead Publishing., 2010, 665-697.
10. Muzaffar, K.; Nayik, G.A.; Kumar, P. J. Nutr. Food Sci., 2015, 12, 1-3.

11. O'callaghan, D.; Hogan, S. Dairy Sci. Technol., 2013, 93, 331-346.

12. Lee, T.; Chang, G.D. Cryst. Growth Des., 2009, 9, 3551-3561.

13. Kawakami, K.; Miyoshi, K.; Tamura, N.; Yamaguchi, T.; Ida, Y. J. Pharm. Sci., 2006, 95, 1354-1363.

14. Morrow, E.A.;Terban, M.W.;Thomas, L.C.; Gray, D.L.; Bowman, M.J.; Billinge, S.J.L.; Schmidt, S.J. J. Food Eng., 2019, 243, 125-141.

15. Hebbar, K.; Pandiselvam, R.; Manikantan, M.; Arivalagan, M.; Shameena, B.; Chowdappa, P. Sugar Tech., 2018, 20, 621-634.

16. Imtiaz-UI-Islam, M.; Langrish, T.A. Food Bioprod. Process., 2009, 87, 87-95.

17. Simperler, A.; Kornherr, A.; Chopra, R.; Bonnet, P.A.; Jones, W.; Motherwell, W.D.S.; Zifferer, G. J. Phys. Chem. B., 2006, 110, 19678-19684.

18. Khuenpet, K.; Nutcha, C.; Sasarose, J.; Supha, A.; Weerachet, J. Agric. Nat. Resour. J., 2016, 50, 139-145.

19. Chong, S.Y.; Wong, C.W. Int. Food Res. J., 2017, 24, 2543-2548. 